\title{
SUBTITUSI BUBUK BIJI SALAK DAN BUBUK KOPI ARABIKA DALAM PEMBUATAN BUBUK KOPI
}

\section{SUBTITUTION SEED POWDER OF SALAK AND ARABICA COFFEE POWDER IN MAKING COFFEE POWDER}

\author{
Devi Lestari1), Kadirman2), Patang ${ }^{3)}$, \\ 1)Mahasiswa Program Studi Pendidikan Teknologi Pertanian, Fakultas Teknik, \\ Universsitas Negeri Makassar \\ 2) dan 3)Dosen Fakultas Teknik, Universitas Negeri Makassar \\ devilestari06@gmail.com
}

\begin{abstract}
ABSTRAK
Penelitian ini bertujuan untuk mengetahui kemungkinan subtitusi bubuk biji salak dan bubuk kopi arabika untuk dijadikan alternatif bubuk kopi dan perbandingan bubuk biji salak dan bubuk kopi arabika yang paling diminati panelis. Parameter yang diamati meliputi uji proksimat yaitu karbohidrat, protein, kadar air, kadar abu, kadar kafein, dan uji organoleptik yang terdiri dari warna, aroma dan rasa. Hasil penelitian menunjukkan bahwa subtitusi bubuk biji salak terhadap bubuk kopi arabika memungkinkan dilakukan pencampuran, dimana berdasarkan hasil uji hedonik yang terdiri dari warna, aroma, dan rasa menunjukkan nilai rata-rata sebesar 6,12-7,31 yang berarti layak dan perlakuan terbaik terletak pada pelakuan A ( $25 \%$ bubuk biji salak dan $75 \%$ bubuk kopi arabika). Hasil uji proksimat menunjukkan kandungan karbohidrat tertinggi terletak pada perlakuan $D$ (100\% bubuk biji salak), sedangkan kandungan protein tertinggi terletak pada perlakuan $\mathrm{K}$ (100\% bubuk kopi arabika), selanjutnya kadar abu dan kadar kafein terendah terletak pada perlakuan $\mathrm{D}$ dan kadar air terendah terletak pada perlakuan $\mathrm{K}$.
\end{abstract}

Kata kunci : Subtitusi, Bubuk Biji Salak, Bubuk Kopi Arabika

\begin{abstract}
This research aims to find out the possibility of substitution seed powder of salak and arabica coffee powder to be used as an alternative the coffee powder and comparison of seed powder of salak and arabica coffee powder to most panelist favored. The observed parameters proximate test namely carbohydrates, protein, moisture content, ash content, caffeine content, and organoleptic test, which consists of color, scent of and flavor. Research results show that the substitution seed powder of salak to arabica coffee powder is enabling do the mixing, based on test results hedonic which consists of color, scent of and flavor shows the average value of 6,12-7,31 which mean decent and the best treatment lies in the A treatment (25\% seed powder of salak and $75 \%$ Arabika coffee powder). Proximate of test results showed the highest carbohydrate content lies on $D$ treatment $(100 \%$ seed powder of salak), while the highest protein content lies on the $K$ treatment (100\% Arabica coffee powder), fhurthermore the lowest ash content and the lowest caffeine levels is contained on the $D$ treatment and low water content is contained on the $\mathrm{K}$ treatment.
\end{abstract}

Keywords: Substitution, Seed Powder of Salak, Arabica Coffee Powder 


\section{PENDAHULUAN}

Salak (Salacca zalacca) merupakan tanaman asli Indonesia yang buahnya banyak digemari masyarakat karena rasanya manis dan kandungan gizi yang tinggi. Salak mempunyai masa depan yang cerah untuk dikembangkan baik untuk memenuhi pasaran lokal ataupun pasaran luar negeri. Salak adalah tanaman dari famili palmae dengan buah yang bisa dimakan. Konsumen umumnya menyukai salak yang daging buahnya tebal, rasanya manis dan bijinya kecil. Produksi salak di Indonesia setiap tahunnya selalu meningkat. Menurut Kementerian Pertanian Republik Indonesia (2013), produksi salak di Indonesia dalam 3 tahun terakhir, 2010, 2011, dan 2012 berturut-turut mencapai 749.876, 1.082.115, dan 1.035.406 ton.

Tanaman Salak Enrekang merupakan salah satu komoditas unggulan di Kabupaten Enrekang, Sulawesi Selatan. Masyarakat pada umumnya mengkomsumsi buah salak sebagai buah meja karena rasanya yang manis dan memiliki daging buah yang tebal. Sektor pertanian sangat penting peranannya dalam perekonomian di Kabupaten Enrekang. Ketersediaan sarana dan prasarana sosial ekonomi di KTE masih dianggap tertinggal dibandingkan dengan $\mathrm{KBE}$, sehingga sangat potensial untuk pengembangan pertanian seperti tanaman pangan/hortikultura, perkebunan dan pengembangan hutan rakyat. Sentra tanaman salak banyak terdapat di Desa Cece, Kecamatan Alla, Kabupaten Enrekang. Salak memberikan sumbangan produksi yang banyak terhadap masyarakat di wilayah Kecamatan Alla. Peningkatan produksi salak setiap tahunnya membuat masyarakat di daerah Kalosi, Kecamatan Alla kemudian mengolah salak menjadi kripik salak sebagai oleh-oleh khas dari Kabupaten Enrekang, Sulawesi Selatan. Salak tentunya memberikan satu dampak yang tidak bisa dihindarkan, yakni bertambahnya limbah buah salak yang terdiri atas kulit dan biji salak. Limbah salak yang bersifat kasar dan keras cukup menyulitkan untuk dapat diolah menjadi bahan yang dapat dimakan. Oleh karena itu, untuk meningkatkan nilai ekonomis dari limbah biji salak, maka diduga dapat diolah menjadi bubuk biji salak. Biji salak banyak memiliki antioksidan. Hasil uji fitokimia menunjukkan biji salak mengandung senyawa flavonoid dan tannin serta sedikit alkaloid. Kandungan flavonoid mampu menurunkan kadar glukosa dalam darah (Saputra, 2008). Senyawa antioksidan memegang peranan penting dalam pertahanan tubuh terhadap pengaruh buruk yang disebabkan radikal bebas.

Kopi adalah salah satu minuman khas yang banyak disukai orang. Pada umumnya kopi terbuat dari biji kopi asli. Pada umumnya, kopi dikonsumsi oleh masyarakat dalam bentuk bubuk yang diseduh menggunakan air panas. Kopi mengandung kafein yang apabila dikonsumsi secara berlebihan dapat berdampak bagi kesehatan seperti insomnia (susah tidur) dan berbahaya bagi penderita hipertensi (darah tinggi).

Untuk mengatasi hal tersebut maka bobot kopi harus dikurangi dengan cara menambahkan bahan yang mengandung gizi yang dibutuhkan oleh tubuh sehingga dapat bermanfaat bagi kesehatan terutama bagi penderita hipertensi (darah tinggi). Biji salak dapat dijadikan sebagai bahan tambahan dalam pembuatan kopi karena 
mengandung gizi yang dibutuhkan oleh tubuh sehingga menjadi produk yang fungsional dan aman bagi kesehatan terutama bagi penderita hipertensi. Penelitian ini diharapkan dapat memberikan sumbangan bagi masyarakat sekitar dan dunia wirusaha.

\section{Tujuan Penelitian}

Penelitian ini bertujuan untuk mengetahui kemungkinan subtitusi bubuk biji salak terhadap bubuk kopi arabika dapat dijadikan alternatif dalam pembuatan kopi bubuk dan berapa perbandingan bubuk biji salak terhadap bubuk kopi arabika yang paling diminati panelis dalam pembuatan kopi bubuk.

\section{METODOLOGI PENELITIAN}

Jenis Penelitian ini termasuk penelitian eksperimen kuantitatif dengan menggunakan Rancangan Acak Lengkap (RAL), dimana terdapat 4 perlakuan $(A=$ Bubuk biji salak $25 \%+$ Bubuk kopi arabika 75\%, B = Bubuk biji salak 50\% + Bubuk kopi arabika 50\%, C $=$ Bubuk biji salak $75 \%+$ Bubuk kopi arabika 25\%, D = Bubuk biji salak 100\%) dan 1 kontrol ( $\mathrm{K}=$ Bubuk kopi arabika $100 \%$ ).

Bahan yang digunakan yaitu; biji salak dan bubuk kopi arabika Peralatan yang digunakan dalam penelitian ini yaitu; baskom plastik atau wadah, termometer, alat tumbuk, timbangan digital, wajan, gelas ukur, pisau, kompor, ayakan, cabinet dryer, spatula, tabung gas elpiji, blender,

Tahap pertama yaitu alur proses pembuatan biji salak menjadi bubuk biji salak yaitu sortasi dan pembersihan biji salak yang bertujuan untuk menghilangkan kotoran yang melekat pada kulit biji salak, pencucian dengan air bersih, pembelahan, pengeringan dengan menggunakan cabinet dryer dengan suhu terkontrol yaitu suhu $60^{\circ} \mathrm{C}$ selama 18 jam (Gumawang, 2015), penyangraian selama 30 menit dengan suhu $\pm 180^{\circ} \mathrm{C}$, pendinginan selama $5-10$ menit menggunakan kipas angin, penghalusan dengan blender, pengayakan hingga lolos ayakan 60 mesh sehingga menghasilkan bubuk biji salak yang halus. Setelah itu dilakukan pengukuran kadar air.

Pembuatan biji arabika menjadi bubuk kopi arabika yaitu penyangraian biji arabika kering dengan suhu $\pm 200^{\circ} \mathrm{C}$ selama 30 menit, pendinginan selama 5 10 menit, penggilingan menggunakan mesin penghalus, pengayakan hingga lolos 60 mesh untuk menghasilkan bubuk yang halus. Kemudian dilakukan perhitungan nilai uji proksimat (karbohidrat, protein, kadar air, abu, dan kafein),dan uji organoleptik (warna, aroma dan rasa). Perlakuan dilakukan ulangan sebanyak tiga kali.

Penelitian ini dilaksanakan di Laboratorium Pendidikan Teknologi Pertanian Fakultas Teknik Universitas Negeri Makassar.

Data pada penelitian ini diperoleh dari hasil pengujian karakteristik organoleptik dengan menggunakan metode uji mutu hedonik yang dilakukan dengan menguji seberapa jauh tingkat penerimaan panelis terhadap karakteristik bubuk kopi yang meliputi warna, aroma, dan rasa. Panelis yang dilibatkan dalam pengujian ini yaitu panelis semi terlatih (semitrained panel) yang terdiri dari 25 orang dari kalangan mahasiswa. Data yang diperoleh dianalisis menggunakan analisis statistik sidik ragam ANOVA yang dilanjutkan dengan uji lanjut DMRT. 


\section{HASIL DAN PEMBAHASAN}

\section{Karbohidrat}

Kadar karbohidrat merupakan komponen yang sangat dibutuhkan tubuh. Karbohidrat merupakan sumber energi bagi tubuh manusia. Analisis kadar karbohidrat dilakukan untuk mengetahui kandungan karbohidrat yang terdapat pada bubuk kopi arabika dan bubuk biji salak.

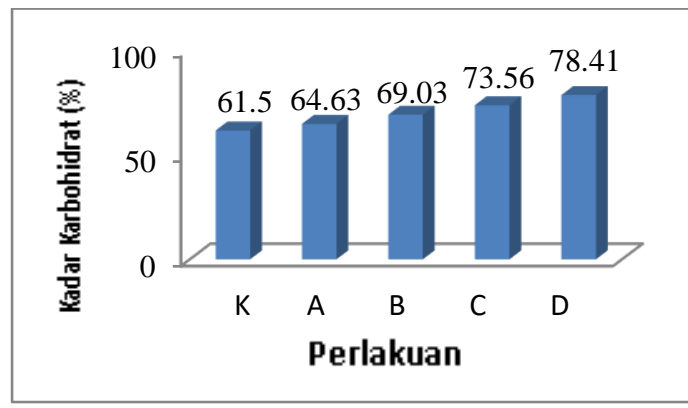

Gambar 1

Hasil Uji Kadar Karbohidrat Subtitusi Bubuk Biji Salak

Ket :

K: $100 \%$ bubuk kopi arabika (kontrol),

A: $25 \%$ bubuk biji salak $+75 \%$ bubuk kopi arabika,

B: $50 \%$ bubuk biji salak $+50 \%$ bubuk kopi arabika,

C: $75 \%$ bubuk biji salak $+25 \%$ bubuk kopi arabika,

D: $100 \%$ bubuk biji salak,

Berdasarkan Gambar 1 menunjukkan kadar karbohidrat bubuk kopi arabika subtitusi bubuk biji salak mengalami peningkatan. $\mathrm{Hal}$ ini dikarenakan kandungan utama dari bubuk biji salak yaitu selulosa sehingga semakin tinggi konsentrasi penambahan bubuk biji salak, maka total karbohidrat produk akan semakin meningkat. Hasil uji karbohidrat pada bubuk biji salak yaitu perlakuan D (100\% bubuk biji salak) sebesar $78,41 \%$ lebih rendah dari hasil penelitian Gumawang (2015) yaitu biji salak sangrai sebesar 91,83\%-92,77\% dan lebih tinggi dari hasil penelitian Aji (2012) yaitu 38,9\%.

Karbohidrat subtitusi bubuk biji salak terhadap bubuk kopi arabika berpengaruh terhadap rasa yang dihasilkan, dimana semakin tinggi konsentrasi bubuk biji salak maka rasa yang dihasilkan tidak terlalu pahit karena bubuk biji salak mengandung karbohidrat (gula) yang lebih tinggi yaitu sebesar $78,41 \%$.

\section{Protein}

Reaksi antara protein dan gula pereduksi merupakan sumber utama menurunnya nilai gizi protein pangan selama pengolahan. Hal ini sesuai pendapat Singh (2007) yang menyatakan bahwa reaksi Maillard antara protein dan gula menurunkan kandungan protein, tergantung pada bahan baku dan komposisinya.

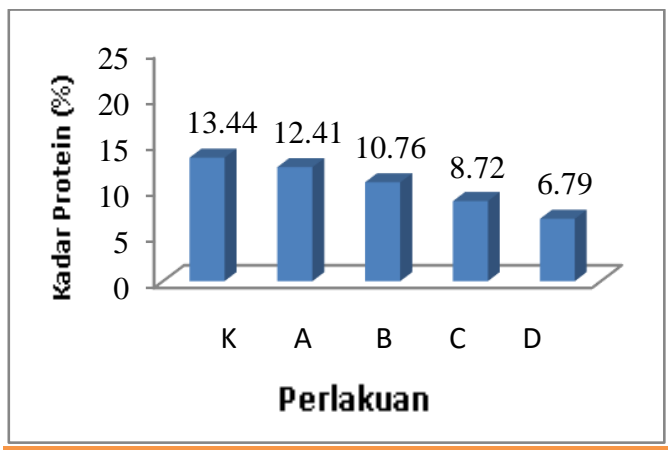

Gambar 2

Hasil Uji Kadar Protein Subtitusi Bubuk

Biji Salak

Ket :

K: $100 \%$ bubuk kopi arabika (kontrol),

A: $25 \%$ bubuk biji salak $+75 \%$ bubuk kopi arabika,

B: $50 \%$ bubuk biji salak $+50 \%$ bubuk kopi arabika,

C: $75 \%$ bubuk biji salak $+25 \%$ bubuk kopi arabika,

D: $100 \%$ bubuk biji salak, 


\begin{abstract}
Berdasarkan Gambar 2 menunjukkan kadar protein pada bubuk kopi arabika subtitusi bubuk biji salak mengalami penurunan. Hal ini disebabkan karena perbedaan konsentrasi antara bubuk kopi arabika dan bubuk biji salak. Sehingga dapat dikatakan bahwa semakin tinggi konsentrasi bubuk biji salak maka kadar protein semakin rendah. Kadar protein pada perlakuan D $(100 \%$ bubuk biji salak) yaitu sebesar $6,79 \%$ masih lebih tinggi dibandingkan dengan hasil penelitian Gumawang (2015) sekitar 3,26\%-3,62\% maupun Aji (2012) sebesar $4,22 \%$.

Kadar protein subtitusi bubuk biji salak berpengaruh terhadap kualitas kopi seperti rasa kopi yang dihasilkan, hal ini sesuai pendapat Israyanti (2012) yang menyatakan bahwa semakin rendah protein maka rasa kopi jadi semakin tidak pahit.
\end{abstract}

\section{Kadar Air}

Air merupakan zat gizi yang diperlukan dalam berbagai proses fisiologis dan biokimiawi tubuh. Namun kadar air yang tinggi dalam produk kering seperti bubuk kopi menurunkan daya simpannya. Syarat mutu kadar air kopi bubuk yaitu maksimal $7 \%$. Analisa kadar air dilakukan untuk mengetahui tingkat kadar air pada substitusi bubuk biji salak. Jumlah kadar air yang terdapat pada bahan sangat penting dalam mempertahankan daya simpan bahan tersebut. Selain itu kadar air dalam bahan pangan juga ikut berperan dalam pembentukan sifat organoleptik produk. Kadar air awal biji salak Enrekang yaitu sebesar $51,85 \%$. Hasil ini tidak berbedah jauh dengan penelitian Aji (2012) bahwa kadar air biji salak yaitu sebesar $54,84 \%$.

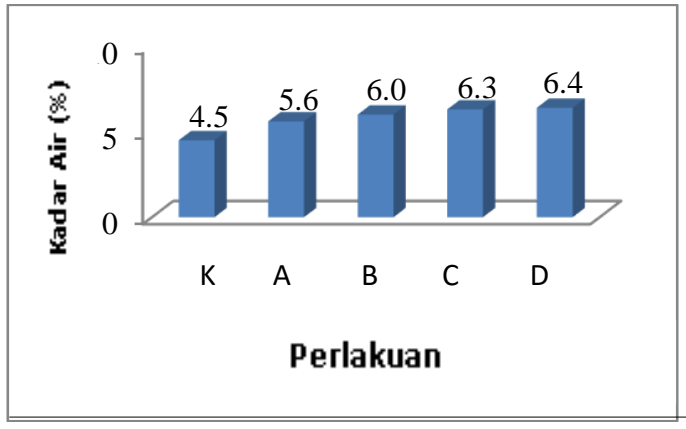

\section{Gambar 3}

Hasil Uji Kadar Air Subtitusi Bubuk Biji Salak

Ket :

K: $100 \%$ bubuk kopi arabika (kontrol),

A: $25 \%$ bubuk biji salak $+75 \%$ bubuk kopi arabika,

B: $50 \%$ bubuk biji salak $+50 \%$ bubuk kopi arabika,

C: $75 \%$ bubuk biji salak $+25 \%$ bubuk kopi arabika,

D: $100 \%$ bubuk biji salak,

\section{Berdasarkan Gambar 3} menunjukkan kadar air masing-masing perlakuan berbeda hal ini disebabkan karena adanya perbedaan konsentrasi bubuk biji salak dan bubuk kopi arabika yang diberikan, dimana semakin banyak penambahan konsentrasi bubuk biji salak maka semakin tinggi kadar airnya. Selain itu, besar kecilnya kadar air pada biji kopi arabika dan biji salak yang telah disangrai dapat dipengaruhi oleh suhu dan lama penyangraian. Dimana semakin lama waktu dan suhu penyangraian maka kadar air semakin kecil. Hal ini sesuai dengan Estiasih (2009) bahwa semakin besar perbedaan suhu antara medium pemanas dengan bahan pangan semakin cepat pindah panas ke bahan pangan dan semakin cepat pula penguapan air dari bahan pangan.

Kadar air berpengaruh terhadap citarasa dan aroma bubuk kopi karena kadar air yang tinggi akan menyabkan aroma yang kurang segar dan cita rasa 
yang kurang baik. Hal ini sesuai dengan pernyataan Winarno, dkk. (2003), bahwa air merupakan komponen terpenting dalam bahan makanan, karena air mempengaruhi penampakan, tekstur, serta citarasa makanan. Hasil penelitian ini telah memenuhi persyaratan SNI bubuk kopi yang telah ditetapkan yaitu maksimal 7\%. Sehingga dapat dikatakan bahwa subtitusi bubuk biji salak terhadap bubuk kopi arabika layak dikonsumsi.

\section{Kadar Abu}

Kadar abu merupakan campuran dari komponen anorganik atau mineral yang terdapat pada suatu bahan pangan. Bahan pangan terdiri dari $96 \%$ bahan anorganik dan air, sedangkan sisanya merupakan unsur-unsur mineral.

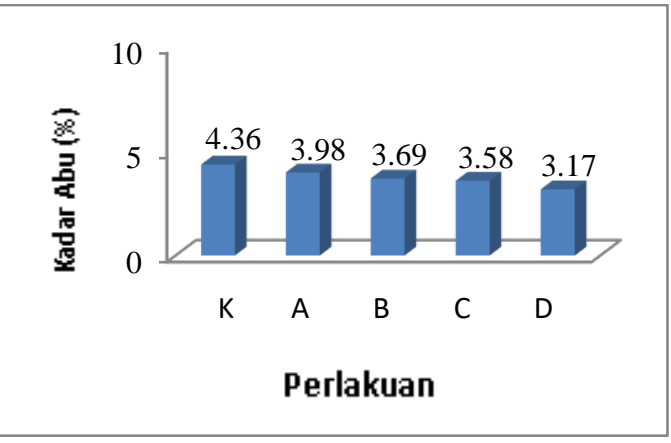

Gambar 4

Hasil Uji Kadar Abu Subtitusi Bubuk Biji Salak

Ket :

K: $100 \%$ bubuk kopi arabika (kontrol),

A: $25 \%$ bubuk biji salak $+75 \%$ bubuk kopi arabika,

B: $50 \%$ bubuk biji salak $+50 \%$ bubuk kopi arabika,

C: $75 \%$ bubuk biji salak $+25 \%$ bubuk kopi arabika,

D: $100 \%$ bubuk biji salak,

Hasil analisis uji kadar abu bubuk kopi substitusi bubuk biji salak pada berbagai perlakuan pada Gambar 4 menunjukkan kadar abu subtitusi bubuk biji salak mengalami penurunan seiring dengan penambahan bubuk biji salak, hal ini diduga disebabkan karena adanya perbedaan konsentrasi bubuk biji salak dan bubuk kopi arabika, dimana semakin tinggi konsentrasi bubuk biji salak akan semakin rendah kadar abunya. Besar kecilnya kadar abu pada biji kopi arabika dan biji salak yang telah disangrai dapat dipengaruhi oleh suhu dan lama penyangraian. Dimana semakin lama waktu dan suhu penyangraian maka kadar abu semakin besar seiring berkurangnya kadar air. Suhu dan lama penyangraian berpengaruh terhadap kadar abu. Semakin tinggi suhu dan lama penyangraian maka semakin tinggi pula kadar abu dan semakin rendah kadar air yang dihasilkan.

Berdasarkan penelitian Aji (2012) yang menyatakan bahwa kadar abu biji salak yaitu 1,56\%. Kadar abu bubuk biji salak dalam penelitian ini lebih tinggi yaitu sebesar $3,17 \%$. Hasil ini dapat dikatakan baik karena telah memenuhi syarat dengan standar yang ditetapkan oleh SNI yaitu maksimal $5 \%$.

\section{Kafein}

Menurut SNI 01-7152-2006 batas maksimum kafein dalam makanan dan minuman adalah $150 \mathrm{mg} / \mathrm{hari}$ dan 50 $\mathrm{mg} / \mathrm{sajian}$.

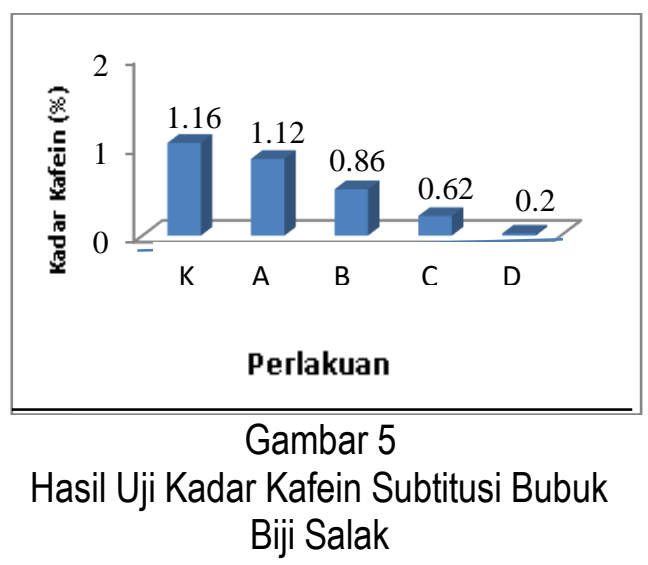


Ket :

K: $100 \%$ bubuk kopi arabika (kontrol),

A: $25 \%$ bubuk biji salak $+75 \%$ bubuk kopi arabika,

B: $50 \%$ bubuk biji salak $+50 \%$ bubuk kopi arabika,

C: $75 \%$ bubuk biji salak $+25 \%$ bubuk kopi arabika,

D: $100 \%$ bubuk biji salak,

Berdasarkan Gambar 5 Kadar kafein untuk semua perlakuan yang dicobakan adalah berbeda nyata. Akan tetapi kadar kafein dari masing-masing perlakuan telah memenuhi syarat komposisi bubuk kopi. Menurut Ridwansyah (2003) syarat kadar kafein bubuk kopi Arabika berkisar antara 0,1$1,2 \%$.

Tinggi rendahnya kadar kafein digunakan sebagai pertimbangan untuk menentukan rumus pencampuran suatu resep campuran kopi bubuk (Septianus, 2009). Kadar kafein subtitusi bubuk biji salak berpengaruh terhadap rasa kopi yang dihasilkan, sehingga dapat dikatakan semakin tinggi konsenstrasi bubuk biji salak maka rasa yang dihasilkan tidak terlalu pahit.

\section{Warna}

Warna merupakan salah satu parameter fisik suatu bahan pangan yang penting. Kesukaan konsumen terhadap produk pangan dipengaruhi oleh warna pangan. Di antara sifat-sifat produk pangan, warna merupakan faktor mutu yang paling menarik perhatian konsumen dan paling cepat memberikan kesan disukai atau tidak disukai (Soekarto, 1985).

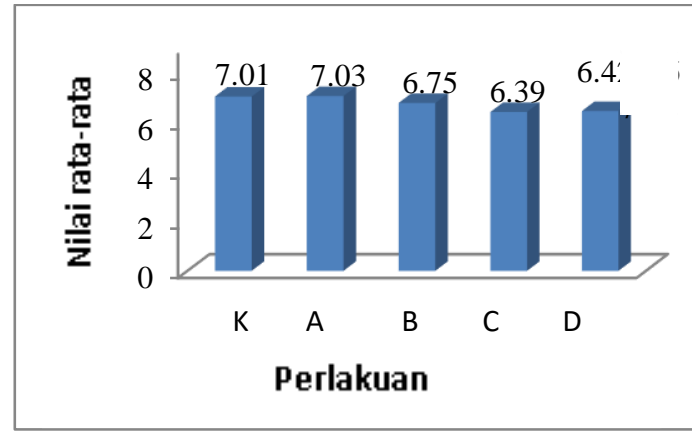

\section{Gambar 6}

Hasil Uji Sensorik terhadap Warna

Substitusi Bubuk Biji Salak Ket :

K: $100 \%$ bubuk kopi arabika (kontrol),

A: $25 \%$ bubuk biji salak $+75 \%$ bubuk kopi arabika,

B: $50 \%$ bubuk biji salak $+50 \%$ bubuk kopi arabika,

C: $75 \%$ bubuk biji salak $+25 \%$ bubuk kopi arabika,

D: $100 \%$ bubuk biji salak,

Berdasarkan uji organoleptik menunjukkan hasil subtitusi bubuk biji salak terhadap bubuk kopi arabika diperoleh rata-rata warna kopi agak hitam hingga hitam. Hal ini disebabkan karena perbandingan bubuk kopi arabika yang lebih banyak menghasilkan warna yang lebih pekat. Hal tersebut terjadi karena adanya proses karamelisasi pada bahan yaitu biji salak dan biji kopi arabika yang mengandung gula. Faktor lama penyangraian juga mempengaruhi warna kopi. Lama penyangraian 16 menit menghasilkan produk kopi yang lebih tua. Semakin lama proses penyangraian maka warna akan semakin tua (Mulato, 2002).

\section{Aroma}

Aroma merupakan sifat mutu yang sangat cepat memberikan kesan bagi konsumen, karena aroma merupakan faktor yang sangat berpengaruh pada daya terima 
konsumen terhadap suatu produk. Soekarto (1985) menyatakan bahwa aroma suatu produk dalam banyak hal menentukan bau atau tidaknya suatu produk, bahkan aroma atau bau lebih kompleks dari pada rasa.

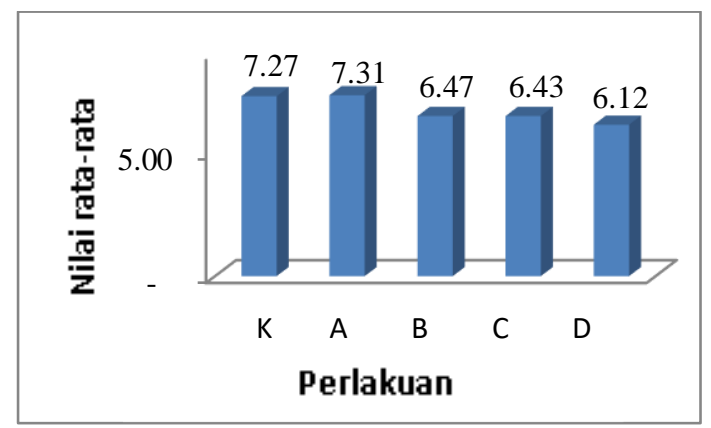

Gambar 7

Hasil Uji Sensorik terhadap Aroma

Substitusi Bubuk Biji Salak

Ket :

K: $100 \%$ bubuk kopi arabika (kontrol),

A: $25 \%$ bubuk biji salak $+75 \%$ bubuk kopi arabika,

B: $50 \%$ bubuk biji salak $+50 \%$ bubuk kopi arabika,

C: $75 \%$ bubuk biji salak $+25 \%$ bubuk kopi arabika,

D: $100 \%$ bubuk biji salak,

Berdasarkan uji organoleptik menunjukkan hasil subtitusi bubuk biji salak, menurut angket yang diisi oleh 25 panelis diperoleh rata-rata aroma yang kurang tajam hingga aroma yang tajam/khas kopi pada umumnya. Hal ini disebabkan karena jika semakin banyak perbandingan bubuk kopi arabika maka aroma yang dihasilkan semakin tajam/khas, bubuk kopi arabika mengandung asam amino dan gula jika disangrai akan menghasilkan aroma yang khas.

\section{Rasa}

Daya terima terhadap bahan pangan juga dipengaruhi oleh rasa. Rasa merupakan factor yang berpengaruh dalam penerimaan konsumen terhadap produk olahan pangan. Selain faktor tekstur, aroma dan warna, seringkali rasa lebih dominan dipertimbangkan oleh kosumen dibandingkan sifat mutu lainnya.

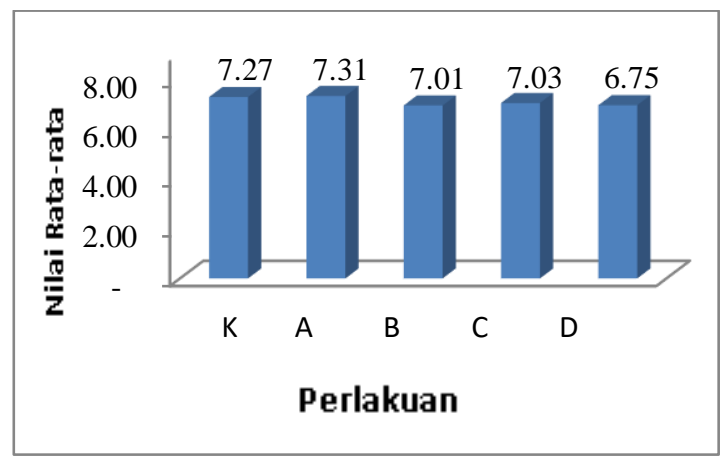

Gambar 8

Hasil Uji Sensorik terhadap Rasa

Substitusi Bubuk Biji Salak

Ket :

K: 100\% bubuk kopi arabika (kontrol),

A: $25 \%$ bubuk biji salak $+75 \%$ bubuk kopi arabika,

B: $50 \%$ bubuk biji salak $+50 \%$ bubuk kopi arabika,

C: $75 \%$ bubuk biji salak $+25 \%$ bubuk kopi arabika,

D: $100 \%$ bubuk biji salak,

Berdasarkan uji organoleptik menunjukkan hasil subtitusi bubuk biji salak terhadap bubuk kopi arabika diperoleh rata-rata rasa kopi yang kurang pahit hingga pahit. Oktadina (2013) mengungkapkan bahwa proses penyangraian membentuk aroma dan citarasa khas kopi karena perlakuan panas. Sehingga semakin lama penyangraian maka semakin didapatkan cita rasa kopi yang baik. Sebagian besar panelis menyebutkan bahwa pada perlakuan A lebih cenderung terasa pahit, hal ini dikarenakan perbandingan bubuk biji salak lebih sedikit dibanding bubuk kopi arabika (25\% : $75 \%$ ). Selain itu, kandungan kafein pada bubuk kopi 
arabika memberikan pengaruh terhadap rasa kopi. Hal ini sesuai dengan pernyataan Yusianto dkk (2002), senyawa kafein memberikan cita rasa khas kopi yaitu pahit sehingga menjadikan kopi sebagai minuman yang digemari oleh banyak orang.

Menurut Ramalaksmi (1999), kafein merupakan salah satu komponen yang sangat penting berhubungan langsung dengan sifat fisiologis kopi, kafein akan menentukan tingkat rasa pahit kopi ketika diseduh.

\section{Daya Terima}

Atribut penerimaan merupakan suatu atribut yang penting dalam hal penerimaan suatu produk sebelum produk tersebut dilepas ke pasaran. Panelis telah memilih bahwa perlakuan $\mathrm{A}$ (25\% bubuk biji salak dan $75 \%$ bubuk kopi arabika) diterima. Namun, sebagian panelis juga mengemukakan bahwa pelakuan D (100\% bubuk biji salak) tidak berbeda dengan bubuk kopi pada umumnya. Selain itu, perlakuan D $(100 \%$ bubuk biji salak) telah memenuhi syarat mutu bubuk kopi pada umumnya seperti kadar air, kadar abu, kafein, dan mengandung karbohidrat yang tinggi dan kafein yang rendah sehingga aman dikonsumsi oleh masyarakat. Sehingga dapat dikatakan bahwa perlakuan D (100\% bubuk biji salak) dapat dijadikan alternatif dalam pembuatan bubuk kopi.

\section{KESIMPULAN}

Subtitusi bubuk biji salak
terhadap bubuk kopi arabika
memungkinkan dilakukan pencampuran,
dimana kandungan karbohidrat paling
tinggi, kadar kafein paling rendah, dan
kadar abu paling rendah terletak pada
pada perlakuan D $(100 \%$ bubuk biji
salak), sedangkan kadar protein tertinggi dan kadar air terendah terletak pada perlakuan K (100\% bubuk kopi arabika).

Hasil uji mutu hedonik yang terdiri atas warna, aroma, dan rasa yang terbaik terletak pada perlakuan A $(25 \%$ bubuk biji salak dan $75 \%$ bubuk kopi arabika) yang memiliki karbohidrat $64,63 \%$, protein $12,41 \%$, kadar air $5,6 \%$, kadar abu 3,98\%, dan kafein 1,12\%.

\section{DAFTAR PUSTAKA}

Aji, B. K. dan F. Kurniawan. 2012. Pemanfaatan Serbuk Biji Salak (Salacca zalacca) sebagai Adsorben $\mathrm{Cr}(\mathrm{VII})$ dengan Metode Batch dan Kolom. Jurnal Sains POMITS.

Estiasih, T. dan Ahmadi, K (2009). Teknologi Pengolahan Pangan. Jakarta: PT. Bumi Aksara.

Gumawang, A. 2015. Pengaruh Cara Pengeringan Biji Salak Gading, Pondoh Manggala, Dan Pondoh Lumut Terhadap Sifat Kimia, Fisik, Sensoris, Dan Aktivitas Antioksidan Bubuk Biji Salak Sangrai. Fakultas Teknologi Pertanian, Universitas Gadjah Mada. Yogyakarta.

Israyanti, 2012. Perbandingan Karakteristik Kimia Kopi Luwak dan Kopi Biasa dari Jenis Kopi Arabika (caffea arabika. L) dan Robusta (Caffea cenephora. L). Fakultas Pertanian. Universitas Hasabuddin. Makassar.

Kementerian Pertanian Republik Indonesia. 2013. Basis Data Statistik Pertanian. http://aplikasi.deptan.go.id/bdsp. Diakses pada 14 November 2013. 
Mulato, Sri. 2002. Simposium Kopi 2002 dengan tema "Mewujudkan Perkopian Nasilonal Yang Tangguh Melalui Diversifikasi Usaha Berwawasan Lingkungan Dalam Pengembangan Industri Kopi Bubuk Skala Kecl Untuk Meningkatkan Nilai Tambah Usaha Tani Kopi Rakyat". Denpasar. Pusat penelitian kopi dan kakao indonesia.

Ramealaksmi, K.I.K and L.J.M. Raghavan. 1999. Antioxidant Potential of Low-Grade Coffee Beans, Food Research International.

Ridwansyah.2003.PengolahanKopi.http:/ /repository.usu.ac.id/bitstream/123 456789/776/3/tekperridwansyah4. pdf.txt.Jurusan Teknologi Pertanian Fakultas Pertanian Universitas Sumatra Utara. Diakses tanggal 15 November 2013.

Saputra, B. I. 2008. Desain Sistem Adsorpsi. Jakarta: Universitas Indonesia.

Singh, G. P., Ganapathi, M., \& Dash, D. (2007). Role Of Intrinsic Disorder In Transient Interactionts Of Hub Proteins. Proteins.

Soekarto, 1985. Penilaian Organoleptik Untuk Industri Pangan Dan Hasil Pertanian. Pusat Pengembangan Teknologi Pangan, IPB, Bogor.

Oktadina, Fiona Drefin; dkk. 2013. "Pemanfaatan Nanas ( Annanas Comosus L. Merr) Untuk Penurunan Kadar Kafein Dan Perbaikan Cita Rasa Kopi (Coffea Sp) Dalam Pembuatan Kopi
Bubuk". Jurnal keteknikan pertanian tropis dan biosistem

Winarno $H$, Ohashi $K$, Mukai M, Simanjuntak P, Shibuya H. 2003. Uji Bioaktivitas terhadap Invasi Sel Kanker dari Beberapa Senyawaan Flavonoid, Santin, Terpen, dan Ligan yang Diisolasi dari Benalu the (Scurrulla atropurpurea) Lorantaceae.Proseding Seminar dan Pameran Nasional Tumbuhan Obat Indonesia XXIV.Pusat Studi Biofarmaka LP-IPB Darmaga, Bogor.

Yusianto dan Mulato, S. 2002. Pengolahan Dan Komposisi Kimia Biji Kopi: Pengaruhnya Terhadap Cita Rasa Seduhan. Materi pelatihan uji cita rasa kopi. Jember: pusat penelitan kopi dan kakao Indonesia. 